\title{
Reason for Immigration and Immigrant's Health
}

\author{
Osea Giuntella, PhD \\ osea.giuntella@pitt.edu \\ Assistant Professor \\ University of Pittsburgh \\ Zovanga Kone, $\mathrm{PhD}$ \\ zovanga.kone@compas.ox.ac.uk \\ Researcher \\ University of Oxford \\ Isabel Ruiz, PhD \\ Isabel.ruiz@hmc.ox.ac.uk \\ Economics Fellow \\ University of Oxford \\ Carlos Vargas-Silva, PhD (contact author) \\ carlos.vargas-silva@compas.ox.ac.uk \\ Associate Professor and Senior Researcher \\ University of Oxford
}




\section{Reason for immigration and immigrant's health}

Objectives: The existing literature on the health trajectories of UK immigrants has mainly focused on the relationship between ethnicity and health. There is little information on the role of immigration status and no previous information on the role of reason for immigration to the country. This study fills this gap in the literature by analysing the heterogeneity of immigrantnative differences in health by reason for immigration.

Study design: Analysis of cross-sectional quarterly data from the UK Labour Force Survey covering the period of 2010 (quarter 1) to 2017 (quarter 2). The sample includes 345,086 observations. The dependent variables of interest include suffering from a long-lasting condition, the link between long-lasting conditions and labour market performance, and the prevalence of 12 specific health conditions.

Methods: Data were analysed using linear probability models to adjust for differences in age, education, gender, ethnicity, local authority of residence and year. The analysis also explores the role of length of stay in the UK and the percentage of current lifetime spent in the UK (duration in the UK/age).

Results: Results indicate that, in general, immigrants are less likely than natives to report suffering from a long-lasting (one year or more) health problem. This pattern generally remains the same when we consider the specificity of the long-lasting health problem. However, there are key differences across the immigrant groups by reason for immigration. Those who migrated for employment, family and study reasons report better health outcomes than natives, while those who migrated to seek asylum report worse health outcomes than natives. There is convergence to natives' health outcomes over time for those who migrated for non-asylum reasons, but not for those who migrated to seek asylum. 
Conclusions: The findings show that the prevalence of health problems differs not only between natives and immigrants, but also across groups of immigrants who moved to the UK for different reasons.

Keywords: immigration, health, labour markets, UK 


\section{Introduction}

The UK has one of the largest stocks of foreign-born residents among OECD countries. ${ }^{\mathrm{i}}$ Between 1993 and 2015 the country's foreign-born population more than doubled, going from 3.8 million ( $7 \%$ of the population) to 8.7 million (14\% of the population). ${ }^{\text {ii }}$ In the public debate there is a general concern that immigration may negatively affect access to public services, such as health care, ${ }^{\mathrm{iii}}$ and it has been suggested that concerns related to immigration were a key driver of the UK's vote to leave the European Union. ${ }^{\text {iv }}$ The impact of immigration on the demand for health services would largely depend on the health status and health trajectories of immigrants. However, while there is a large literature on the relationship between ethnicity and health outcomes in the UK, ${ }^{\mathrm{v}, \text { vivii }}$ there is little information on the role of immigration status and even less information on the role of reason for immigration to the country.

This article explores differences in health outcomes between the foreign-born (i.e. immigrant) and UK-born (i.e. native) populations. The analysis explores a range of health outcomes and distinguishes immigrants by reason for immigration (employment, study, family, asylum). While there is a substantial literature exploring the health outcomes of immigrants in the United States and Europe, ${ }^{\text {vii,ix }}$ studies accounting for heterogeneity in health outcomes across immigrant groups by route of entry are scarce., ${ }^{\mathrm{x} x i}$ Key factors related to route of entry include experiences during the immigration process and degrees of access to health services in the host country after arrival. ${ }^{\text {ii }}$

Our analysis looks at 12 health outcomes and information on whether health conditions affect labour market activities. The analysis further explores the role of length of residence in the country and whether there are any signs of convergence in outcomes across groups over time.

Identifying how particular health conditions differ across immigrant groups will help inform strategic policy interventions directed at improving the health outcomes of the immigrant population. The study is also important for the discussion of the economic integration of 
immigrants as different health conditions (e.g. physical limitation versus mental health) may have different effects on labour market performance. ${ }^{\text {xii,xiv }}$

\section{Method}

The study is based on analyses of the UK's quarterly Labour Force Survey (LFS). The LFS is the UK's largest sample survey and it is intended to be representative of the population. The sample of the addresses surveyed is randomly drawn from a list of residential delivery addresses points for Royal Mail. The data used in this study cover the period between the first quarter of 2010 and the second quarter of 2017 (30 quarters) and only includes individuals who are interviewed in the LFS for the first time in that quarter. The choice of the period covered by the data is due to the fact that it was not until 2010 that the LFS included a question which asks foreign-born respondents about their main reason for migrating to the UK. The five categories of reason for immigration are: (1) employment; (2) study; (3) family re-unification; (4) asylum; (5) other. In total we have a sample of 345,086 respondents who were at least 16 years of age in 2010 and at most 64 years of age in 2017.

As shown in Table 1, close to $17 \%$ of those in the sample are foreign-born (i.e. 58,036 respondents). We also disaggregate them by reason for immigration and length of residence. The main reasons for immigration are family reunion and employment. Close to $7 \%$ of the sample are family immigrants (40\% of all immigrants) while 5\% are employment immigrants $32 \%$ of all immigrants). Close to $5 \%$ of those in the sample are immigrants who have been living in the UK for five years or less (28\% of all immigrants) and 3\% have been living in the UK for over 25 years (20\% of all immigrants).

[Table 1]

The LFS collects information on an array of self-reported health outcomes. We start by constructing three outcome variables that are based on responses to the following questions: (1) "Do you have any health problems or disabilities that you expect will last for more than a year?"; (2) "Does this health problem affect the kind of paid work that you might do?"; and (3) "Does 
this health problem affect the amount of paid work that you might do?”. Questions (2) and (3) are asked of the economically active who responded yes to question (1). We assign a value 1 to our outcome variables when the response is "yes" and value 0 if the response is "no". We consider (1) as relating to long-lasting conditions; (2) as relating to limitations of work types; and (3) as relating to limitations of work hours.

Respondents with a long-lasting health problem (i.e. those who answered yes to question (1)) are asked to specify whether they were suffering from any the following 12 health problems:

- Cardiovascular (including heart, blood pressure, blood circulation, other)

- Respiratory (including breathing problems, asthma, bronchitis, other)

- Diabetes

- Mental (including phobias, panics, depression, bad nerves, anxiety, other)

- Back and/or neck

- Sensory (e.g. seeing, hearing, speaking, other)

- Skin (severe disfigurement, skin conditions, allergies, other)

- Digestive (stomach, liver, kidney, digestive, others)

- Limbs (arms, hands, legs, feet, includes arthritis or rheumatism)

- Epilepsy

- Learning difficulties

- Progressive (cancer, multiple sclerosis, symptomatic HIV, Parkinson's disease, muscular, other)

We first compute the rates of prevalence of the aforementioned health problems across groups (i.e. mean values of the health problem dummies). We then estimate various linear probability models controlling for relevant demographic characteristics. The first estimated equation is as follows:

$$
y_{i, t}=\alpha+\beta_{1} \text { Immigrant }_{i, t}+\beta_{2} L A_{i, t}+\beta_{3} \text { Year }_{t}+\theta X_{i, t}+\varepsilon_{i, t}
$$

In this case $y$ is the health outcome of interest, Immigrant is the foreign-born dummy, $L A$ and Year control for local authority of residence and year, while $X$ includes a set of controls for demographic differences (age, education, gender, and ethnicity). $\varepsilon$ is the error term. The coefficient of interest is $\beta_{1}$, the estimated adjusted difference in prevalence rates of particular health problems (i.e. means of $y$ ) between natives and immigrants. 
Next we substitute the immigrant dummy with dummies indicating reason for immigration to the country (i.e. employment, study, family, asylum, other) in order to explore differences across those groups. That is, we estimate:

$$
\begin{array}{r}
y_{i, t}=\alpha+\beta_{1} \text { Employment }_{i, t}+\beta_{2} \text { Study }_{i, t}+\beta_{3} \text { Family }_{i, t}+\beta_{4} \text { Asylum }_{i, t}+\beta_{5} \text { Other }_{i, t} \\
+\beta_{6} L A_{i, t}+\beta_{7} \text { Year }_{t}+\theta X_{i, t}+\varepsilon_{i, t}
\end{array}
$$

We also estimate equations (1) and (2) adding interactions between the ethnic groups and reason for immigration. Given limitations of space, the results of these are presented in the supplementary material accompanying this article.

We also include country of origin dummies as an additional control in one of the estimations. This procedure has the advantage of allowing (an average) comparison of differences in health outcomes for individuals from the same country who migrated for different reasons. However, in order to include this variable, we need to limit the sample to immigrants only. Here, the reference category is employment immigrants. Exploring the role of country of origin is important as our estimation is based on self-reported health which captures current health and potentially also cultural expectations about what health should be.

In a third step, we explore whether length of residence in the UK can explain the differences in health outcomes between natives and each of the immigrant groups. To this end we replace the immigrant dummy with indicators of length of stay in the UK (LUK): 0-5 years, 610 years, 11-15 years, 16-20 years, 21-25 years, over 25 years. We present the results for this third step in a chart. The estimated equation is:

$$
y_{i, t}=\alpha+\sum_{d=1}^{6} \beta_{d} L U K_{i, t}+\beta_{7} L A_{i, t}+\beta_{8} \text { Year }_{t}+\theta X_{i, t}+\varepsilon_{i, t}
$$

In addition, we also show results where we replace absolute measures of duration in the UK with duration in the UK as a percentage of current lifetime, i.e. the ratio of duration in the UK and age.

All statistical analyses are conducted using STATA version 13. 


\section{Results}

\section{Differences between natives and immigrants}

Table 2 reports mean values for the health outcomes of interest. The proportion of those who report suffering from a long-lasting condition (i.e. a problem which is expected to last 12 months or more) is lower for immigrants compared to natives (i.e. $32 \%$ of natives suffer from a longlasting condition compared to $22 \%$ of immigrants). This differs from many studies in Europe in which immigrants self-report having poorer health than natives, ${ }^{9, x v}$ but is in line with studies for the United States in which immigrants tend to self-report better health than the native-born. ${ }^{8}$ Furthermore, having a health condition is less likely to affect labour market performance of immigrants relative to natives. While $30 \%$ of the UK-born respondents reported that the longlasting condition affected the number of hours they could work, this was only the case for $25 \%$ of the foreign-born. This pattern generally remains the same for most conditions.

\section{[Table 2]}

Table 3 reports the coefficients of the immigrant dummy and dummies for reason for immigration from linear probability models in which the health outcome is the dependent variable. These adjusted estimates reveal that immigrants are 7 percentage points less likely to report a long-lasting condition relative to natives, and 3 percentage points less likely to report that this condition affects their employment options. Looking at particular conditions, immigrants are less likely to report sensory, skin, respiratory, mental, epilepsy, learning difficulties and progressive conditions, but more likely to report cardiovascular, back/neck problems and diabetes.

There is substantial heterogeneity in the health outcomes of immigrants across reasons for immigration as observed in the remaining columns of Table 3, which report differences between the different immigrant groups and natives. For instance, employment and study immigrants are 12 and 10 percentage points, respectively, less likely to report suffering from a long-lasting condition in comparison to natives. For family immigrants this difference is smaller 
in absolute terms, as this group is just 4 percentage points less likely to report suffering from a long-lasting condition in comparison to natives. Meanwhile, asylum immigrants are 7 percentage points more likely to report a long-lasting condition relative to natives.

[Table 3]

Immigrant groups also differ in the type of health conditions that they report. While employment immigrants are 11 percentage points less likely to report mental health conditions than natives, asylum immigrants are 4 percentage points more likely to do so. Additionally, those who migrated for employment reasons are 3 percentage points less likely to report a long-term problem with limbs in comparison to natives, but asylum immigrants are 9 percentage points more likely to report this same type of health problem. Finally, while students are not statistically different from natives in their likelihood of reporting back/neck problems, asylum immigrants are 12 percentage points more likely to do so. These results suggest that failing to disaggregate immigrants by motive for immigration can mask important dynamics related to their health status.

Table 4 reports the differences across immigrant groups once we control for country of origin in the estimation. In this case the reference category is employment immigrants. The analysis suggests that the estimated health differences across immigrant groups do not change much when we control for country of origin.

[Table 4]

\section{Convergence over time}

In Figure 1, we illustrate how differences in health problems between immigrants and natives change with time spent in the UK. Our analysis relies on 30 cross-sections and the estimations are, as such, not adjusted for possible cohort specific differences. In particular, we cannot account for those within each cohort that have returned to their country of origin and previous research has suggested that health status is correlated with the likelihood of return. ${ }^{\text {xvi }}$ While mindful of this limitation, it is still possible to identify an overall pattern: immigrants generally 
start off healthier than natives but converge towards the natives' health levels. As with previous results, it is possible to observe key differences across the immigrant groups. Notably, the differences between the health of asylum immigrants and natives appear largely uncorrelated with length of stay in the UK.

[Figure 1]

In Figure 2, we replace time in the UK with the percentage of her/his current lifetime that the immigrant has spent in the country. In line with Figure 1, the results suggest that those who have spent a higher share of their lifetime in the country have health outcomes which are closer to those of natives. Here, however, asylum immigrants who spent the majority of their lives in the UK exhibit relatively closer health outcomes to natives' than before.

[Figure 2]

\section{Discussion}

This article explored how the health outcomes of immigrants in the UK compare to those of natives. The results suggest that immigrants are healthier than natives upon arriving in the UK, and that their health outcomes converge to those of natives over time. The finding that recent immigrants have, on average, better health outcomes than natives (i.e. healthy immigrant effect), has been found in other contexts. ${ }^{15, x v i i}$ Likewise, studies in other settings have also found that the health status of immigrants converges to that of natives. .viii,xix,xx,xxi $^{\text {. }}$

The novelty of our analysis is to zoom in further and explore the relationship between reason for immigration and health. Only a few studies have provided insights on this aspect. In the case of Australia, for instance, refugee immigrants (followed by preferential family immigrants) are likely to report poorer general health status in comparison to other groups of immigrants while employment immigrants report the best general health status. ${ }^{10}$ Similar results have been found for the United States; refugees and family preference immigrants were found 
less likely to experience positive health selection compared to immigrants with employment visas. ${ }^{11}$ Our results for the UK are in line with these results for Australia and the United States.

In addition, we explored the link between long-lasting health conditions and labour market activities across immigrants with different reasons of immigration. Asylum immigrants who have a long-lasting condition are more likely than natives to report that this condition limits the number of hours that they can work and the type of employment that they can undertake. The story is different for other immigrant groups. For instance, employment and study immigrants are less likely than natives to report that long-lasting conditions affect their labour market performance. Also, there is no significant difference between native and family immigrants regarding the link between long-lasting conditions and labour market performance.

Overall, the results suggest that reason for immigration has substantial implications for health outcomes and studies that ignore this heterogeneity only provide a partial account of the health trajectory of immigrants.

The results have implications for the allocation of health related integration funding and the development of immigration policy. For instance, as reason for immigration relates strongly to health problems that affect labour market engagement for some groups, it might be effective to reallocate funding geared toward the economic integration of these groups (e.g. those who migrated for asylum) to first address health issues that impede labour market performance. Also, the analysis suggests that changes in immigration policy that affect the composition of the immigrant population (e.g. making it more difficult for international students to remain in the country after finishing their studies, while facilitating the settlement of asylum and family immigrants) will have repercussions on the overall demand for health services of the immigrant population - this is in line with studies that have highlighted the implications of different immigration policies for findings such as the "healthy immigrant effect". xxii 


\section{Author statements}

\section{Acknowledgement}

The paper has benefited from insights from close consultations with local government authority representatives and NGOs working with immigrants, asylum seekers and refugees in the UK. The data used come from the secured access version of the UK Labour Force Survey produced by the ONS and supplied by the UK Data Service. The use of the data in this work does not imply the endorsement of ONS or the Secure Data Service at the UK Data Archive in relation to the interpretation or analysis of the data.

\section{Ethical approval}

None required. The study uses secondary data obtained from the UK's Office for National Statistics.

\section{Funding}

This research was funded by the Nuffield Foundation, as part of the project "The Economic Integration of Refugees in the UK", grant number OPD/42744.

\section{Competing interests}

The authors report no conflicts of interest. 


\section{Figures}

Figure 1: Relationship between length of stay in the UK and differences in the likelihood of reporting a long lasting illness between immigrants and natives

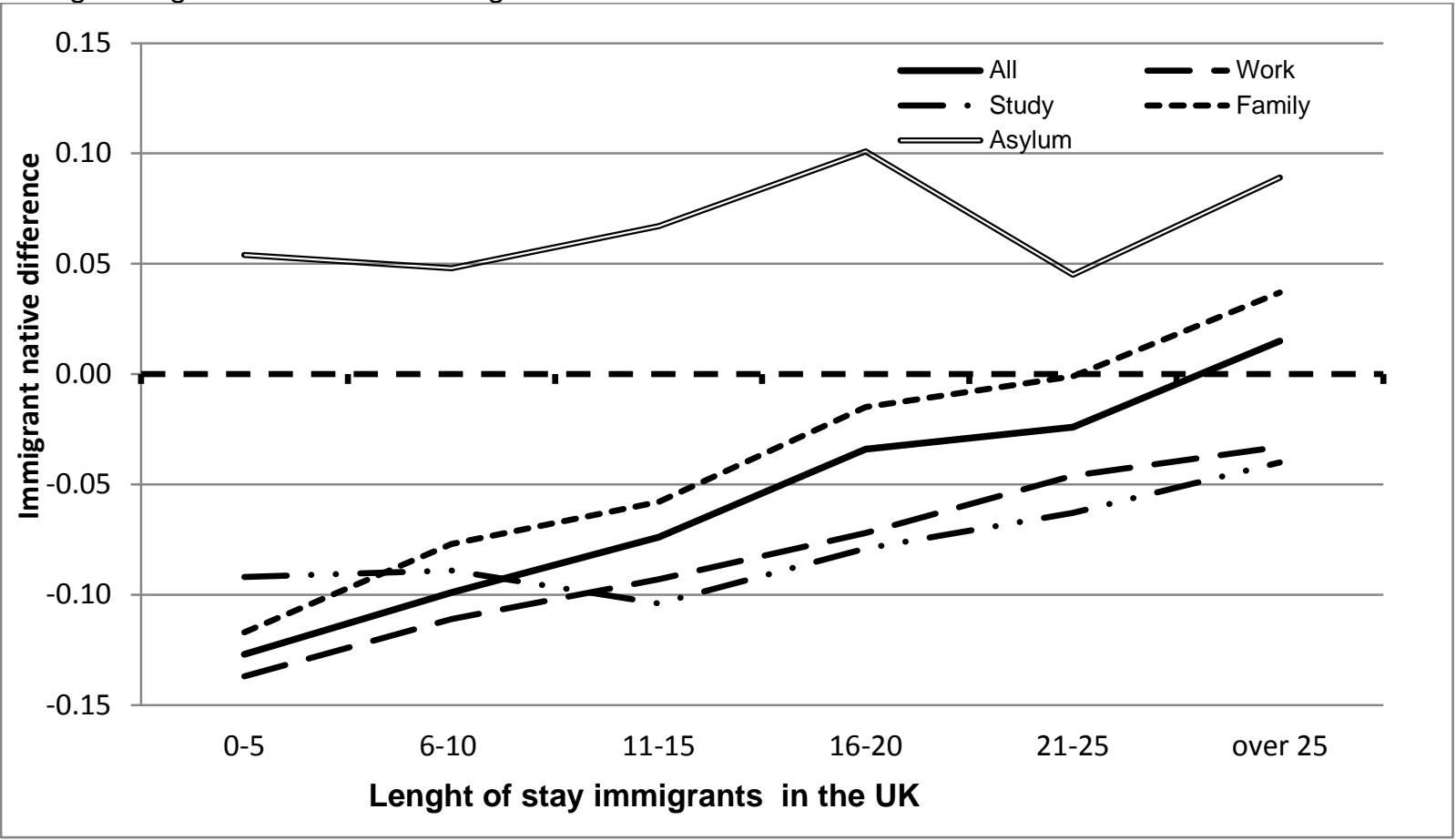

Figure 2: Relationship between length of stay in the UK as proportion of lifetime and differences in the likelihood of reporting a long lasting illness between immigrants and natives

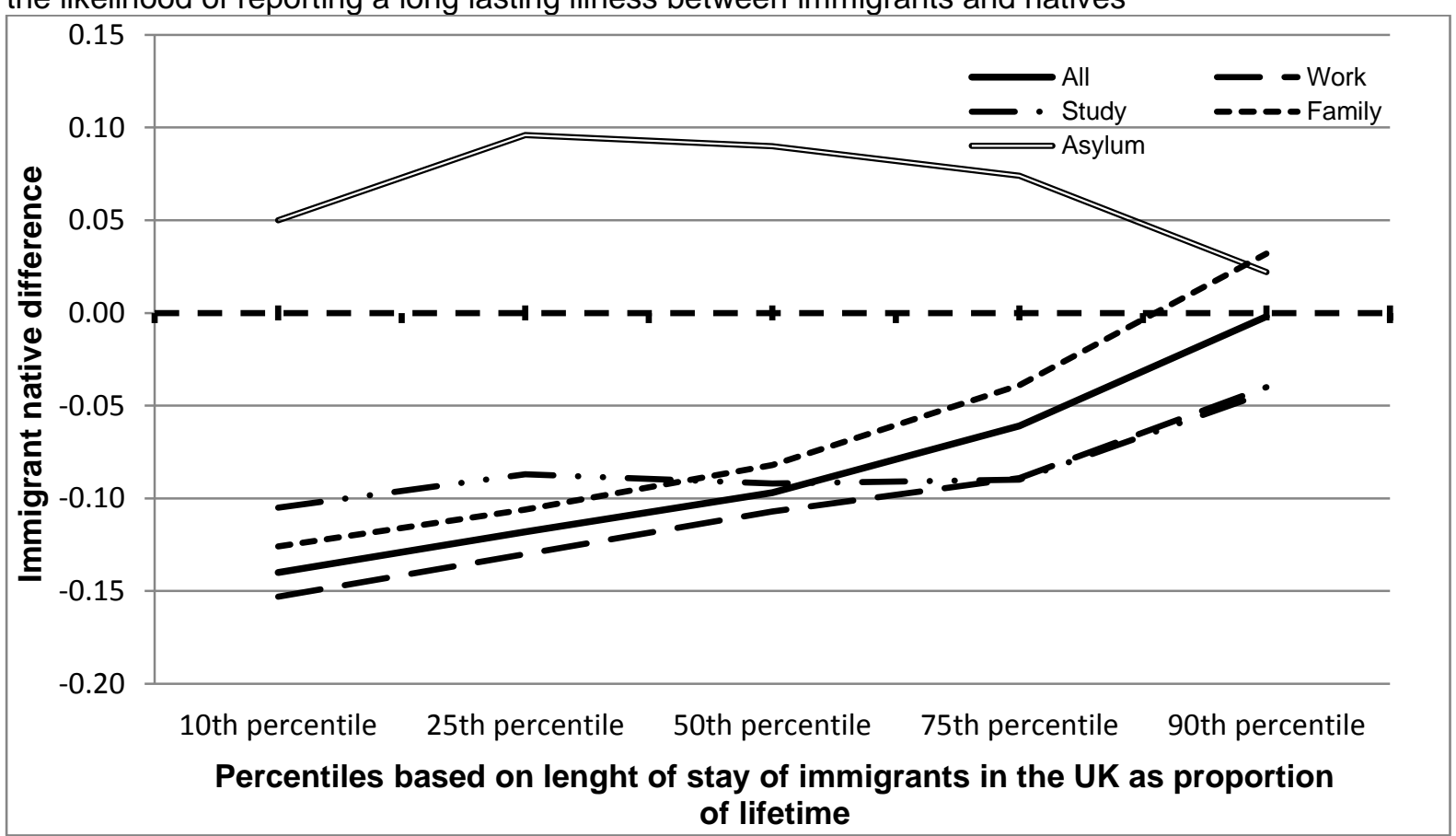




\section{Tables}

Table 1: Distribution of sample

\begin{tabular}{lcc}
\hline Variable & $\mathrm{N}$ & \% of full \\
sample
\end{tabular}


Table 2: Mean values of dummies indicating health problems (yes =1, no =0) among individuals aged 16-64 years based on cross-sectional observations from 2010 to 2017 Labour Force Survey, UK.

\begin{tabular}{|c|c|c|c|c|c|c|c|}
\hline Outcome & UK born & Foreign born & \multicolumn{5}{|c|}{ Reason for immigration of the foreign born } \\
\hline \multirow[t]{2}{*}{ Has a long lasting illness } & 0.32 & $0.22^{* \star *}$ & $0.16^{\star \star *}$ & $0.13^{\star \star \star}$ & $0.27^{\star \star \star}$ & $0.35^{\star \star \star}$ & $0.28^{\star \star \star}$ \\
\hline & \multicolumn{7}{|c|}{ Illness limitations in labour market performance (among those with an illness) } \\
\hline Number of hours worked & 0.30 & $0.25^{\star \star *}$ & $0.15^{\star * \star}$ & $0.15^{\star \star \star}$ & 0.30 & $0.47^{\star \star \star}$ & 0.30 \\
\hline \multirow[t]{2}{*}{ Type of work } & 0.34 & $0.27^{\star \star *}$ & $0.17^{\star \star *}$ & $0.16^{* * *}$ & $0.33^{\star \star \star}$ & $0.48^{\star * *}$ & $0.32^{*}$ \\
\hline & \multicolumn{7}{|c|}{ Type of illness (among those with an illness) } \\
\hline Limbs & 0.27 & $0.26^{* \star *}$ & $0.21^{* * *}$ & $0.19^{* \star \star}$ & 0.27 & $0.33^{\star \star \star}$ & 0.28 \\
\hline Back/Neck & 0.23 & $0.24^{\star \star \star}$ & 0.23 & $0.17^{\star \star \star}$ & $0.24^{\star *}$ & $0.30^{\star \star \star}$ & $0.27^{\star \star *}$ \\
\hline Sensory & 0.08 & $0.06^{* \star *}$ & $0.04^{* * *}$ & $0.05^{* * *}$ & $0.07^{\star \star \star}$ & 0.07 & $0.06^{\star * *}$ \\
\hline Skin condition & 0.07 & $0.05^{\star \star \star}$ & $0.05^{* * *}$ & 0.07 & $0.05^{\star \star *}$ & $0.03^{\star \star \star}$ & $0.05^{\star * *}$ \\
\hline Mental & 0.23 & $0.16^{* * *}$ & $0.10^{* * *}$ & $0.14^{* * *}$ & $0.17^{\star * *}$ & 0.22 & $0.19^{\star * *}$ \\
\hline Progressive & 0.05 & $0.04^{* * *}$ & $0.04^{* * *}$ & $0.04^{* * *}$ & $0.04^{\star \star *}$ & $0.03^{\star \star \star}$ & $0.04^{* * *}$ \\
\hline Epilepsy & 0.03 & $0.01^{* \star *}$ & $0.01^{* \star *}$ & $0.01^{* \star *}$ & $0.02^{\star \star \star}$ & $0.02^{\star *}$ & $0.02^{\star * *}$ \\
\hline Learning difficulty & 0.03 & $0.01^{* * *}$ & $0.00^{* * *}$ & $0.01^{* * *}$ & $0.01^{* * *}$ & $0.01^{\star * *}$ & $0.02^{\star * *}$ \\
\hline
\end{tabular}


Table 3: Conditional differences in rates of prevalence of health problems between natives and immigrants aged 16-64 years based on cross-sectional observations from 2010 to 2017 Labour Force Survey, UK

\begin{tabular}{|c|c|c|c|c|c|c|}
\hline \multirow{2}{*}{ Outcome } & \multirow{2}{*}{ Foreign born } & \multicolumn{5}{|c|}{ Reason for immigration of the foreign born } \\
\hline & & Employment & Study & Family & Asylum & Other \\
\hline \multirow[t]{3}{*}{ Has a long-lasting illness } & $-0.070^{\star \star *}$ & $-0.115^{\star \star \star}$ & $-0.097^{* \star *}$ & $-0.036^{\star \star *}$ & $0.069^{* * *}$ & $-0.026^{* *}$ \\
\hline & $(-30.88)$ & $(-39.40)$ & $(-22.82)$ & $(-10.78)$ & $(7.66)$ & $(-4.15)$ \\
\hline & \multicolumn{6}{|c|}{ Illness limitations in labour market performance (among those with an illness) } \\
\hline \multirow{2}{*}{ Number of hours worked } & $-0.028^{\star * \star}$ & $-0.070^{\star \star \star}$ & $-0.074^{\star \star \star}$ & -0.002 & $0.156^{\star \star \star}$ & 0.012 \\
\hline & $(-8.12)$ & $(-16.04)$ & $(-10.44)$ & $(-0.40)$ & (11.98) & (1.32) \\
\hline \multirow{2}{*}{ Type of work } & $-0.033^{\star * \star}$ & $-0.081^{\star * *}$ & $-0.086^{\star * \star}$ & -0.001 & $0.140^{\star * \star}$ & 0.006 \\
\hline & $(-9.61)$ & $(-18.04)$ & $(-11.76)$ & $(-0.17)$ & $(10.80)$ & $(0.64)$ \\
\hline
\end{tabular}

Type of illness (among those with an illness)

\begin{tabular}{|c|c|c|c|c|c|c|}
\hline Limbs & $\begin{array}{l}-0.004 \\
(-0.72)\end{array}$ & $\begin{array}{c}-0.030^{* * *} \\
(-3.73)\end{array}$ & $\begin{array}{c}-0.024^{* *} \\
(-2.00)\end{array}$ & $\begin{array}{l}0.004 \\
(0.64)\end{array}$ & $\begin{array}{c}0.094^{* * *} \\
(5.94)\end{array}$ & $\begin{array}{l}0.013 \\
(1.10)\end{array}$ \\
\hline Back/Neck & $\begin{array}{c}0.033^{\star \star \star} \\
(6.48)\end{array}$ & $\begin{array}{c}0.039^{\star \star *} \\
(4.65)\end{array}$ & $\begin{array}{l}-0.01 \\
(-0.82)\end{array}$ & $\begin{array}{c}0.023^{\star * \star} \\
(3.57)\end{array}$ & $\begin{array}{c}0.116^{\star * \star} \\
(7.42)\end{array}$ & $\begin{array}{c}0.057^{\star \star *} \\
(4.74)\end{array}$ \\
\hline Sensory & $\begin{array}{c}-0.014^{\star \star \star} \\
(-4.72)\end{array}$ & $\begin{array}{c}-0.028^{* \star \star} \\
(-6.55)\end{array}$ & $\begin{array}{c}-0.019^{\star \star \star} \\
(-2.83)\end{array}$ & $\begin{array}{l}-0.005 \\
(-1.31)\end{array}$ & $\begin{array}{l}-0.005 \\
(-0.60)\end{array}$ & $\begin{array}{c}-0.016^{* \star} \\
(-2.52)\end{array}$ \\
\hline Skin condition & $\begin{array}{c}-0.009^{* * *} \\
(-3.11)\end{array}$ & $\begin{array}{c}-0.011^{* *} \\
(-2.51)\end{array}$ & $\begin{array}{l}0.004 \\
(0.45)\end{array}$ & $\begin{array}{c}-0.008^{* *} \\
(-2.09)\end{array}$ & $\begin{array}{c}-0.034^{* * *} \\
(-5.29)\end{array}$ & $\begin{array}{l}-0.010^{*} \\
(-1.71)\end{array}$ \\
\hline Cardiovascular & $\begin{array}{c}0.011^{\star *} \\
(2.32)\end{array}$ & $\begin{array}{c}0.016^{* *} \\
(2.03)\end{array}$ & $\begin{array}{l}0.005 \\
(0.46)\end{array}$ & $\begin{array}{l}0.008 \\
(1.33)\end{array}$ & $\begin{array}{l}0.005 \\
(0.37)\end{array}$ & $\begin{array}{l}0.014 \\
(1.25)\end{array}$ \\
\hline Respiratory & $\begin{array}{l}-0.050^{\star * *} \\
(-10.94)\end{array}$ & $\begin{array}{c}-0.071^{\star * *} \\
(-10.23)\end{array}$ & $\begin{array}{c}-0.060^{* * *} \\
(-5.33)\end{array}$ & $\begin{array}{c}-0.035^{\star \star *} \\
(-5.79)\end{array}$ & $\begin{array}{c}-0.070^{* * *} \\
(-5.73)\end{array}$ & $\begin{array}{c}-0.050^{* * *} \\
(-5.10)\end{array}$ \\
\hline Stomach & $\begin{array}{l}-0.004 \\
(-0.97)\end{array}$ & $\begin{array}{l}-0.009 \\
(-1.46)\end{array}$ & $\begin{array}{l}0.003 \\
(0.31)\end{array}$ & $\begin{array}{l}-0.006 \\
(-1.31)\end{array}$ & $\begin{array}{l}0.028^{\star \star} \\
(2.40)\end{array}$ & $\begin{array}{l}0.004 \\
(0.41)\end{array}$ \\
\hline Diabetes & $\begin{array}{c}0.018^{\star \star *} \\
(5.49)\end{array}$ & $\begin{array}{c}0.026^{\star \star *} \\
(4.19)\end{array}$ & $\begin{array}{l}0.014 \\
(1.50)\end{array}$ & $\begin{array}{c}0.012^{\star \star *} \\
(2.63)\end{array}$ & $\begin{array}{l}0.021^{*} \\
(1.73)\end{array}$ & $\begin{array}{c}0.027^{\star \star \star} \\
(2.99)\end{array}$ \\
\hline Mental & $\begin{array}{c}-0.051^{\star \star *} \\
(-11.09)\end{array}$ & $\begin{array}{c}-0.106^{\star \star \star} \\
(-16.82)\end{array}$ & $\begin{array}{c}-0.063^{\star \star *} \\
(-5.76)\end{array}$ & $\begin{array}{c}-0.034^{\star \star \star} \\
(-5.73)\end{array}$ & $\begin{array}{c}0.039^{\star \star *} \\
(2.73)\end{array}$ & $\begin{array}{l}-0.016 \\
(-1.50)\end{array}$ \\
\hline Progressive & $\begin{array}{c}-0.006^{* *} \\
(-2.22)\end{array}$ & $\begin{array}{c}-0.007^{\star *} \\
(-1.97)\end{array}$ & $\begin{array}{c}0.00 \\
(-0.02)\end{array}$ & $\begin{array}{l}-0.004 \\
(-1.34)\end{array}$ & $\begin{array}{l}-0.004 \\
(-0.55)\end{array}$ & $\begin{array}{l}-0.011^{\star \star} \\
(-2.08)\end{array}$ \\
\hline Epilepsy & $\begin{array}{c}-0.007^{* * *} \\
(-4.10)\end{array}$ & $\begin{array}{c}-0.013^{* * *} \\
(-6.00)\end{array}$ & $\begin{array}{c}-0.012^{\star * *} \\
(-3.71)\end{array}$ & $\begin{array}{l}-0.003 \\
(-1.34)\end{array}$ & $\begin{array}{l}-0.003 \\
(-0.78)\end{array}$ & $\begin{array}{l}-0.005 \\
(-1.32)\end{array}$ \\
\hline Learning difficulty & $\begin{array}{c}-0.019^{\star * *} \\
(-11.28)\end{array}$ & $\begin{array}{c}-0.033^{* \star *} \\
(-20.86)\end{array}$ & $\begin{array}{c}-0.032^{\star \star \star} \\
(-9.98)\end{array}$ & $\begin{array}{c}-0.011^{* * *} \\
(-4.83)\end{array}$ & $\begin{array}{c}-0.026^{* \star *} \\
(-6.36)\end{array}$ & $\begin{array}{c}-0.011^{* * *} \\
(-3.02)\end{array}$ \\
\hline
\end{tabular}


Table 4: Differences in rates of prevalence of health problems among immigrants (those who migrated for employment vs other immigrants) aged 16-64 years based on cross-sectional observations from 2010 to 2017 Labour Force Survey, UK. (1): adjusted differences; (2): extended adjustment with country of origin controls.

\begin{tabular}{|c|c|c|c|c|c|c|c|c|}
\hline \multirow{3}{*}{ Outcome } & \multicolumn{8}{|c|}{ Reason for immigration } \\
\hline & \multicolumn{2}{|c|}{ Study } & \multicolumn{2}{|c|}{ Family } & \multicolumn{2}{|c|}{ Asylum } & \multicolumn{2}{|c|}{ Other } \\
\hline & (1) & $(2)$ & (1) & $(2)$ & (1) & $(2)$ & (1) & $(2)$ \\
\hline Has a long-lasting illness & $\begin{array}{l}-0.002 \\
(-0.38)\end{array}$ & $\begin{array}{l}0.001 \\
(0.13)\end{array}$ & $\begin{array}{c}0.035^{\star * *} \\
(7.67)\end{array}$ & $\begin{array}{c}0.033^{* * *} \\
(7.09)\end{array}$ & $\begin{array}{c}0.154^{* * *} \\
(16.36)\end{array}$ & $\begin{array}{c}0.136^{\star * *} \\
(12.74)\end{array}$ & $\begin{array}{c}0.062^{* \star *} \\
(9.33)\end{array}$ & $\begin{array}{c}0.060^{* * *} \\
(8.82)\end{array}$ \\
\hline & \multicolumn{8}{|c|}{ Illness limitations in labour market performance (among those with an illness) } \\
\hline Number of hours worked & $\begin{array}{c}-0.018^{* *} \\
(-2.15)\end{array}$ & $\begin{array}{l}-0.008 \\
(-0.91)\end{array}$ & $\begin{array}{c}0.034^{* * *} \\
(4.87)\end{array}$ & $\begin{array}{c}0.039^{* * *} \\
(5.42)\end{array}$ & $\begin{array}{c}0.195^{\star * *} \\
(14.56)\end{array}$ & $\begin{array}{c}0.163^{* * *} \\
(10.36)\end{array}$ & $\begin{array}{c}0.058^{\star * *} \\
(5.89)\end{array}$ & $\begin{array}{c}0.064^{* * *} \\
(6.35)\end{array}$ \\
\hline Type of work & $\begin{array}{c}-0.017^{\star \star} \\
(-2.08)\end{array}$ & $\begin{array}{l}-0.010 \\
(-1.11)\end{array}$ & $\begin{array}{c}0.045^{\star \star \star} \\
(6.27)\end{array}$ & $\begin{array}{c}0.048^{\star * *} \\
(6.47)\end{array}$ & $\begin{array}{c}0.192^{\star * *} \\
(14.31)\end{array}$ & $\begin{array}{c}0.159^{\star \star \star} \\
(10.05)\end{array}$ & $\begin{array}{c}0.062^{\star \star \star} \\
(6.11)\end{array}$ & $\begin{array}{c}0.065^{\star * \star} \\
(6.35)\end{array}$ \\
\hline & \multicolumn{8}{|c|}{ Type of illness (among those with an illness) } \\
\hline Limbs & $\begin{array}{l}-0.000 \\
(-0.01)\end{array}$ & $\begin{array}{l}0.005 \\
(0.33)\end{array}$ & $\begin{array}{l}0.017 \\
(1.57)\end{array}$ & $\begin{array}{l}0.018 \\
(1.51)\end{array}$ & $\begin{array}{c}0.119^{\star * *} \\
(6.76)\end{array}$ & $\begin{array}{c}0.104^{\star * *} \\
(5.12)\end{array}$ & $\begin{array}{c}0.034^{\star *} \\
(2.37)\end{array}$ & $\begin{array}{c}0.037^{\star *} \\
(2.49)\end{array}$ \\
\hline Back/Neck & $\begin{array}{c}-0.048^{\star * \star} \\
(-3.36)\end{array}$ & $\begin{array}{c}-0.041^{\star \star *} \\
(-2.75)\end{array}$ & $\begin{array}{l}-0.008 \\
(-0.69)\end{array}$ & $\begin{array}{l}0.001 \\
(0.09)\end{array}$ & $\begin{array}{c}0.081^{* * *} \\
(4.63)\end{array}$ & $\begin{array}{c}0.071^{\star * *} \\
(3.56)\end{array}$ & $\begin{array}{l}0.027^{*} \\
(1.82)\end{array}$ & $\begin{array}{c}0.034^{\star *} \\
(2.29)\end{array}$ \\
\hline Sensory & $\begin{array}{l}0.006 \\
(0.79)\end{array}$ & $\begin{array}{l}0.006 \\
(0.67)\end{array}$ & $\begin{array}{c}0.018^{* * *} \\
(2.98)\end{array}$ & $\begin{array}{c}0.018^{* * *} \\
(2.91)\end{array}$ & $\begin{array}{c}0.024^{\star *} \\
(2.51)\end{array}$ & $\begin{array}{l}0.017 \\
(1.49)\end{array}$ & $\begin{array}{l}0.009 \\
(1.18)\end{array}$ & $\begin{array}{l}0.008 \\
(1.09)\end{array}$ \\
\hline Skin condition & $\begin{array}{l}0.017^{*} \\
(1.90)\end{array}$ & $\begin{array}{l}0.013 \\
(1.38)\end{array}$ & $\begin{array}{l}0.002 \\
(0.36)\end{array}$ & $\begin{array}{l}-0.000 \\
(-0.03)\end{array}$ & $\begin{array}{l}-0.014^{*} \\
(-1.92)\end{array}$ & $\begin{array}{l}-0.009 \\
(-0.96)\end{array}$ & $\begin{array}{l}0.002 \\
(0.31)\end{array}$ & $\begin{array}{l}0.001 \\
(0.12)\end{array}$ \\
\hline Cardiovascular & $\begin{array}{l}-0.005 \\
(-0.35)\end{array}$ & $\begin{array}{l}0.015 \\
(1.00)\end{array}$ & $\begin{array}{l}-0.006 \\
(-0.51)\end{array}$ & $\begin{array}{l}0.014 \\
(1.22)\end{array}$ & $\begin{array}{l}-0.021 \\
(-1.24)\end{array}$ & $\begin{array}{l}0.022 \\
(1.13)\end{array}$ & $\begin{array}{l}-0.002 \\
(-0.15)\end{array}$ & $\begin{array}{l}0.014 \\
(0.94)\end{array}$ \\
\hline Respiratory & $\begin{array}{l}0.008 \\
(0.59)\end{array}$ & $\begin{array}{l}0.008 \\
(0.57)\end{array}$ & $\begin{array}{l}0.016 \\
(1.64)\end{array}$ & $\begin{array}{l}0.009 \\
(0.87)\end{array}$ & $\begin{array}{l}-0.003 \\
(-0.25)\end{array}$ & $\begin{array}{l}-0.012 \\
(-0.78)\end{array}$ & $\begin{array}{l}0.013 \\
(1.12)\end{array}$ & $\begin{array}{l}0.000 \\
(0.00)\end{array}$ \\
\hline Stomach & $\begin{array}{l}0.006 \\
(0.49)\end{array}$ & $\begin{array}{l}0.007 \\
(0.57)\end{array}$ & $\begin{array}{l}0.004 \\
(0.53)\end{array}$ & $\begin{array}{l}0.003 \\
(0.39)\end{array}$ & $\begin{array}{c}0.034^{* * *} \\
(2.60)\end{array}$ & $\begin{array}{l}0.018 \\
(1.21)\end{array}$ & $\begin{array}{l}0.012 \\
(1.09)\end{array}$ & $\begin{array}{l}0.012 \\
(1.12)\end{array}$ \\
\hline Diabetes & $\begin{array}{l}-0.012 \\
(-1.03)\end{array}$ & $\begin{array}{l}-0.008 \\
(-0.67)\end{array}$ & $\begin{array}{c}-0.028^{* * *} \\
(-3.15)\end{array}$ & $\begin{array}{c}-0.030^{\star * *} \\
(-3.25)\end{array}$ & $\begin{array}{l}-0.023^{*} \\
(-1.66)\end{array}$ & $\begin{array}{l}-0.017 \\
(-1.02)\end{array}$ & $\begin{array}{l}-0.007 \\
(-0.59)\end{array}$ & $\begin{array}{l}-0.005 \\
(-0.43)\end{array}$ \\
\hline Mental & $\begin{array}{c}0.026^{\star \star} \\
(2.10)\end{array}$ & $\begin{array}{l}0.013 \\
(1.04)\end{array}$ & $\begin{array}{c}0.035^{\star \star \star} \\
(3.96)\end{array}$ & $\begin{array}{c}0.019^{* *} \\
(2.04)\end{array}$ & $\begin{array}{c}0.122^{* * *} \\
(8.09)\end{array}$ & $\begin{array}{c}0.083^{\star * *} \\
(4.86)\end{array}$ & $\begin{array}{c}0.066^{\star * *} \\
(5.44)\end{array}$ & $\begin{array}{c}0.050^{\star * *} \\
(4.00)\end{array}$ \\
\hline Progressive & $\begin{array}{l}0.002 \\
(0.32)\end{array}$ & $\begin{array}{l}0.002 \\
(0.32)\end{array}$ & $\begin{array}{l}-0.003 \\
(-0.52)\end{array}$ & $\begin{array}{l}-0.003 \\
(-0.57)\end{array}$ & $\begin{array}{l}0.003 \\
(0.38)\end{array}$ & $\begin{array}{l}-0.003 \\
(-0.28)\end{array}$ & $\begin{array}{l}-0.007 \\
(-1.09)\end{array}$ & $\begin{array}{l}-0.009 \\
(-1.28)\end{array}$ \\
\hline Epilepsy & $\begin{array}{l}-0.002 \\
(-0.59)\end{array}$ & $\begin{array}{l}-0.003 \\
(-0.77)\end{array}$ & $\begin{array}{l}0.004 \\
(1.29)\end{array}$ & $\begin{array}{l}0.003 \\
(1.08)\end{array}$ & $\begin{array}{l}0.008^{*} \\
(1.67)\end{array}$ & $\begin{array}{l}0.008 \\
(1.52)\end{array}$ & $\begin{array}{l}0.004 \\
(1.04)\end{array}$ & $\begin{array}{l}0.003 \\
(0.70)\end{array}$ \\
\hline Learning difficulties & $\begin{array}{l}0.002 \\
(0.62)\end{array}$ & $\begin{array}{l}0.001 \\
(0.29)\end{array}$ & $\begin{array}{c}0.013^{\star * *} \\
(5.45)\end{array}$ & $\begin{array}{c}0.012^{\star \star *} \\
(4.81)\end{array}$ & $\begin{array}{c}0.008^{\star *} \\
(2.24)\end{array}$ & $\begin{array}{l}0.006 \\
(1.40)\end{array}$ & $\begin{array}{c}0.013^{\star * *} \\
(3.93)\end{array}$ & $\begin{array}{c}0.012^{\star \star *} \\
(3.39)\end{array}$ \\
\hline
\end{tabular}

Estimates of differences in health outcomes from linear probability models (t statistics in parenthesis). The control group is those who migrated for employment reasons. The stars indicate that the mean value for the outcome of the group is statistically different from the one for the UK born: ${ }^{*} \mathrm{P}<.10 ;{ }^{* *} \mathrm{P}<.05$; and ${ }^{* * *} \mathrm{P}<.01$ 


\section{References}

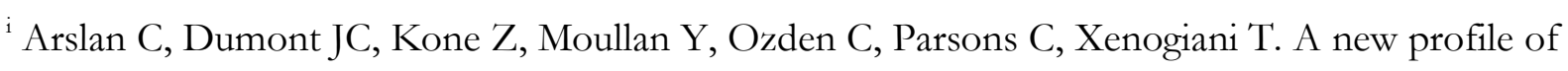
migrants in the aftermath of the recent economic crisis. OECD working paper 2015.

ii Rienzo C, Vargas-Silva C. Migrants in the UK: An Overview. Migration Observatory briefing, COMPAS, University of Oxford, February 2017.

iii Giuntella O, Nicodemo C, Vargas-Silva C. The impact of immigration on health and health care: Evidence from the United Kingdom, in Fasani, F. (eds), Refugees and Economic Migrants: Facts, policies and challenges, CEPR Press 2016.

iv Goodwin MJ, Heath O. The 2016 referendum, Brexit and the left behind: An aggregate-level analysis of the result. The Political Quarterly 2016; 87(3), 323-332.

${ }^{v}$ Landman J, Cruickshank JK. A review of ethnicity, health and nutrition-related diseases in relation to migration in the United Kingdom. Public Health Nutrition 2001; 4(2b), 647-657.

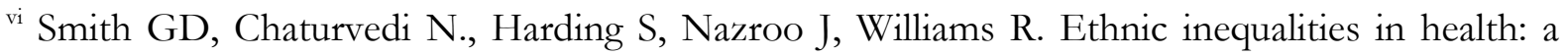
review of UK epidemiological evidence. Critical Public Health 2000; 10(4), 375-408.

vii Jayaweera H, Quigley MA. Health status, health behaviour and healthcare use among migrants in the UK: Evidence from mothers in the Millennium Cohort Study. Social Science \& Medicine 2010; 71(5), 1002-1010.

${ }^{\text {viii }}$ Cunningham, SA, Ruben, JD, Venkat Narayan, KM. Health of foreign-born people in the United States: A review. Health \& Place 2008; 14(4), 623-635.

${ }^{\text {ix }}$ Nielsen, S.S., Krasnik, A. Poorer self-perceived health among migrants and ethnic minorities versus the majority population in Europe: A systematic review. International Journal of Public Health 2010; 55(5), 357-371.

${ }^{x}$ Chiswick BR, Lee YL, Miller PW. Immigrant selection systems and immigrant health. Contemporary Economic Policy 2008; 26(4), 555-578.

${ }^{x i}$ Akresh, IR, Frank, R. Health selection among new immigrants. American Journal of Public Health 2008; 98(11), 2058-2064.

xii Makarova N, Klein-Ellinghaus F, Doetter LF. Applications and limitations of the concept of 'avoidable mortality' among immigrant groups in Europe: a scoping review. Public Health (2015); 129(4), 342-350. 
xiii García-Gómez P, Jones AM, Rice N. Health effects on labour market exits and entries. Labour Economics 2010; 17(1), 62-76.

${ }^{\text {xiv }}$ Ruiz I, Vargas-Silva C. Differences in labour market outcomes between refugees and other migrants: Evidence from the UK. Social Science Research Network, 2017. Available at: https:/ / ssrn.com/abstract $=2920574$.

${ }^{x v}$ Moullan Y, Jusot F. Why is the 'healthy immigrant effect' different between European countries? European Journal of Public Health 2014, 24(1): 80-86.

xvi Sander, M. Return migration and the "healthy immigrant effect". SOEP papers on Multidisciplinary Panel Data Research. DWi Berlin, 2007.

xvii Balcazar AJ, Grineski S E, Collins TW. The Hispanic health paradox across generations: the relationship of child generational status and citizenship with health outcomes. Public Health 2015; 129(6), 691-697.

xviii Antecol H, Bedard K. Unhealthy assimilation: why do immigrants converge to American health status levels? Demography 2006; 43(2), 337-360.

xix Giuntella O. Why does the health of Mexican immigrants deteriorate? New evidence from linked birth records. Journal of Health Economics. 2017 Jul 31;54:1-6.

${ }^{x x}$ McDonald JT, Kennedy S. Insights into the 'healthy immigrant effect': health status and health service use of immigrants to Canada. Social Science \& Medicine 2004; 59(8), 1613-1627.

${ }^{x x i}$ Perez CE. Health status and health behaviour among immigrants [Canadian community health survey-2002 annual report]. Health Reports 2002; 13, 89.

xxii Constant AF, García-Muñoz T, Neuman S, Neuman T. A "healthy immigrant effect” or a "sick immigrant effect"? Selection and policies matter. The European Journal of Health Economics 2017; 1-19. 